\title{
PELATIHAN PERENCANAAN KEUANGAN BAGI LEMBAGA PEMBERDAYAAN PEREMPUAN DAN ANAK (LPPA) WANITA SEJATI
}

\author{
Aria Masdiana Pasaribu ${ }^{1}$, Ferry Safriandi ${ }^{2}$, Windy Aginta ${ }^{3}$ \\ 1,2 Program Studi Akuntansi, Fakultas Ekonomi, Universitas Al-Azhar, Jl. Pintu Air IV No.214, Kwala \\ Bekala, Kec. Medan Johor, Kota Medan, Sumatera Utara 20143 \\ ${ }^{3}$ Program Studi Manajemen, Fakultas Ekonomi, Universitas Al-Azhar, Jl. Pintu Air IV No.214, \\ Kwala Bekala, Kec. Medan Johor, Kota Medan, Sumatera Utara 20143 \\ *ariamasdianapsb1985@gmail.com
}

\begin{abstract}
ABSTRAK. Tujuan kegiatan pengabdian ini adalah untuk melakukan edukasi perencanaan dan pengelolaan keuangan bagi Lembaga Pemberdayaan Perempuan dan Anak (LPPA) Wanita Sejati agar lebih efektif dan optimal sehingga dapat meningkatkan kesejahteraan bagi Lembaga Pemberdayaan Perempuan dan Anak di Kelurahan Rengas Pulau, Medan Marelan. Metode pelaksanaan kegiatan ini adalah ceramah, diskusi dan latihan. Ceramah terdiri dari penyampaian materi terkait dengan definisi sistem pengelolaan keuangan arti penting pengelolaan tersebut untuk kebaikan dan masa depan lembaga tersebut. Peserta juga dilatih untuk membuat anggaran pendapatan dan pengeluaran yang benar secara manual. Peserta kegiatan pengabdian ini adalah kelompok ibu-ibu Lembaga pemberdayaan perempuan Kelurahan Rengas Pulau yang berjumlah sekitar 45 orang. Hasil kegiatan pengabdian adalah $80 \%$ peserta hadir, ini terhitung dari jumlah peserta sekitar 35 orang yang mengikuti kegiatan ini. Sebagian besar peserta telah memahami anggaran pendapatan dan pengeluaran, mampu menyusun skala prioritas kebutuhan serta mampu menyusun anggaran pendapatan dan pengeluaran dengan benar. Kegiatan ini berjalan dengan lancar dan mendapat respons yang sangat positif dari para peserta. Hal ini terlihat dari para peserta yang antusias mengikuti acara dari awal sampai selesai dan aktif berdiskusi mengenai permasalahan seputar pengelolaan keuangan.
\end{abstract}

Kata kunci: Keuangan, Anggaran, Pendapatan, Pengeluaran

ABSTRACT. The purpose of this service activity is to provide education on financial planning and management for Women and Girls Empowerment Institutions to be more effective and optimal to improve welfare for True Women and Girls Empowerment Institutions in Rengas Pulau Village, Medan Marelan. The method of implementing this activity is lectures, discussions, and exercises. The class consisted of delivering material related to the definition of a financial management system and the importance of the institution's promising and future. Participants are also trained to make correct income and expense budgets manually. The participants of this service activity are women from the women's empowerment institution in the Rengas Island Village, totaling about 35 people. The result of the service activity was that $100 \%$ of the participants attended; this was counted from the number of participants, around 35 people who took part in this activity. Most of the participants had understood the income and expenditure budget, were able to prioritize the needs and prepared the income and expenditure budget correctly. This activity went smoothly and received a very positive response from the participants. This can be seen from the participants who enthusiastically participated in the event from start to finish and actively discussed issues related to financial management.

Keywords: Finance, Budget, Income, Expenses

\section{PENDAHULUAN}

Perkembangan dunia industri yang berlangsung pesat menyebabkan terjadinya persaingan yang meningkat antara perusahaan perusahaan dalam memenuhi kebutuhan konsumen. (Siregar dkk., 2020) Saat ini, pengetahuan mengenai keuangan semakin berkembang dan mulai diperkenalkan di berbagai jenjang pendidikan. Praktik $\mathbf{1 7}$ | P a g e pendidikan keuangan juga sangat dekat dan melekat dengan kehidupan sehari-hari seperti bagaimana mempergunakan pendapatan yang diperoleh dan mengelola pendapatan tersebut untuk investasi ataupun untuk kehidupan sehari-hari. Oleh karenanya pendidikan keuangan baik jika diajarkan di usia dini agar kelak ketika beranjak dewasa, seseorang itu 
dapat mengaplikasikan ilmu yang didapatkan dengan baik. Adapun Pengetahuan Keuangan dalam (Halim, Yopie Kurnia Erista \& Astuti, Dewi, 2015) adalah kemampuan untuk memahami, menganalisis dan mengelola keuangan untuk membuat suatu keputusan keuangan yang tepat agar terhindar dari masalah keuangan. Menurut (Mahdzan, Tabiani, 2013) semakin tinggi tingkat pendidikan seseorang maka pengetahuan keuangan seseorang akan mengalami peningkatan yang signifikan.

Kegiatan Pengabdian kepada Masyarakat merupakan salah satu komponen dari Tri Dharma Perguruan Tinggi, selain dua komponen lainnya yaitu penelitian dan pengajaran yang harus dilaksanakan dengan baik. Peran serta dosen dalam Tri Dharma perguruan tinggi dituntut aktif dalam pengembangan sumber daya di masyarakat. Oleh karena itu, keberadaan Perguruan Tinggi tidak dapat terlepas dari konteks masyarakat sekitar. Perguruan Tinggi hendaknya mampu berperan sebagai agen perubahan bagi perbaikan dan peningkatan derajat hidup masyarakat. Salah satu kelompok masyarakat dalam hal ini adalah Lembaga Pemberdayaan Perempuan dan Anak (LPPA) Wanita Sejati. Lembaga Pemberdayaan Perempuan dan Peduli Anak (LPPA) Wanita Sejati, kerap sekali mengadakan pelatihan keterampilan bagi para perempuan di lingkungan tempat tinggalnya, termasuk keterampilan membuat makanan ringan dan mendaur ulang sampah.

Pengabdian ini dinilai sangat perlu dilaksanakan mengingat masih lemahnya sumber daya manusia dalam hal perencanaan keuangan bagi Lembaga Pemberdayaan Perempuan dan Anak di Kelurahan Rengas Pulau, Medan Marelan.

Beberapa permasalahan yang dapat kami rinci adalah sebagai berikut:

1. Latar belakang pendidikan yang umumnya masih rendah.

2. Belum adanya pengalaman dalam penyusunan perencanaan keuangan.

Menurut (Ida \& Dwinta, 2010), untuk memiliki Financial knowledge maka perlu Financial skill dan belajar untuk menggunakan Financial tools.
Kegiatan Pengabdian Kepada Masyarakat ini mempunyai tujuan dan manfaat sebagai berikut:

a. Menjelaskan dan memberikan latihan tentang cara pengelolaan keuangan yang baik dan benar sehingga para peserta lebih terampil.

b. Menjalin hubungan kerja sama dan menjalin silaturahmi antara civitas akademika dengan masyarakat dalam pelaksanaan Tri Dharma Perguruan Tinggi.

c. Mengupayakan sinergitas potensi berbagai pihak yang dapat meningkatkan perkembangan masyarakat khususnya di bidang sosial ekonomi yang berbasis profesionalisme.

Dengan demikian, Tim pelaksana kegiatan Pengabdian Kepada Masyarakat kali ini berupaya memberikan pelatihan untuk melatih dalam hal perencanaan keuangan. Melalui Program Pengabdian kepada Masyarakat, tim pelaksana memberikan pelatihan perencanaan keuangan agar terampil dalam mengelola keuangan. Perencanaan merupakan tindakan yang dibuat berdasarkan fakta dan asumsi mengenai gambaran kegiatan yang dilakukan pada waktu yang akan datang dalam mencapai tujuan yang diinginkan. Perencanaan keuangan yang teratur diharapkan dapat membantu menyusun pelaporan keuangan bagi Lembaga Pemberdayaan Perempuan dan Anak (LPPA) agar lebih baik.

\section{METODE}

Metode pelaksanaan kegiatan Pengabdian Kepada Masyarakat berupa Pelatihan yang terdiri dari beberapa prosedur antara lain:

1. Persiapan

Observasi atau survey kepada sasaran Program Pengabdian Kepada Masyarakat

2. Sosialisasi

Memberikan informasi kepada mitra tentang kegiatan yang akan dilakukan sebagai komitmen untuk menyukseskan Program Pengabdian Kepada Masyarakat. Tim PKM akan memberikan informasi mengenai pentingnya perencanaan keuangan dalam meningkatkan kesejahteraan masyarakat.

3. Persiapan

kegiatan Persiapan kegiatan bertujuan untuk menyiapkan segala kebutuhan pelaksanaan 
kegiatan. Persiapan dilakukan bersama dengan mitra yang meliputi:

a. Persiapan materi/ bahan pelatihan

b. Persiapan tempat, waktu, dan peserta pelatihan

c. Persiapan mekanisme pelaksanaan

4. Pelaksanaan

Pelaksanaan kegiatan pengabdian kepada masyarakat ini menggunakan pendekatan pelatihan dengan metode pembelajaran kooperatif. Kegiatan dilaksanakan dengan metode ceramah, diskusi dan latihan. Adapun peserta dalam pengabdian ini menyangkut ibuibu Lembaga Pemberdayaan Perempuan dan Anak (LPPA) Wanita Sejati, kelurahan Rengas Pulau, Medan Marelan.

\section{HASIL DAN PEMBAHASAN}

Kegiatan yang sudah direncanakan dapat berjalan dengan baik dan lancar. Kegiatan ini menghasilkan bertambahnya wawasan para peserta yang keseluruhannya adalah ibu-ibu. Para ibu dalam kegiatan tersebut menjadi tahu bahwa perencanaan keuangan termasuk dalam hal sebagaimana keuangan di bidang lainnya yang harus dikelola dengan baik. Peserta mendapatkan makna keseimbangan antara pendapatan dengan pengeluaran serta berlatih cara menjaga keseimbangan tersebut dalam mengelola keuangan. Selain itu peserta juga dapat membuat perencanaan yang baik dan benar. Melakukan perencanaan adalah langkah menuju kesuksesan.

Menurut (Widayati, 2012) menyatakan bahwa individu harus memiliki suatu pengetahuan keuangan untuk dapat mengelola keuangannya secara efektif untuk kesejahteraan keuangan individu dengan adanya kecerdasan finansial dalam arti kecerdasan seseorang dalam mengelola keuangan atau aset pribadi. Pengetahuan keuangan dapat diartikan sebagai bagian yang terintegrasi dengan litegasi keuangan, namun kemampuan individu dalam memanfaatkan pengetahuan keuangan. Sedangkan menurut (Permana, 2013), adanya upaya dalam meningkatkan literasi keuangan, yaitu pengetahuan terhadap keuangan, keterampilan dalam mengelola keuangan, dan keyakinan individu sehingga individu dapat mengelola keuangannya secara efektif dan efisien.

Pelatihan ini untuk meningkatkan keterampilan dalam pengelolaan keuangan sesuai teori akuntansi yang disesuaikan dengan pemahaman dan wawasan mitra. Pada tahap ini peserta dilatih melakukan perencanaan keuangan terkait pemasukan dan pengeluaran keuangan yang terjadi dalam Lembaga tersebut. Kegiatan pengabdian kepada masyarakat ini menghasilkan luaran berupa jasa pelatihan kepada kelompok Lembaga Pemberdayaan Perempuan dan Anak (LPPA) Wanita sejati. Pelatihan tersebut merupakan pelatihan perencanaan keuangan. Jadi, para ibu peserta kegiatan ini mendapatkan pelatihan bagaimana mengelola keuangan dengan mengisi beberapa kertas kerja yang sudah dipersiapkan.

Kegiatan pelatihan ini dilaksanakan pada hari Kamis, tanggal 18 Maret 2021 bertempat di Jl. Marelan V Pasar 2 Barat Gg. Mawar 3 Kelurahan Rengas Pulau, Kecamatan Medan Marelan. Peserta dalam pelatihan ini adalah kelompok ibu-ibu Lembaga Pemberdayaan Perempuan berjumlah sekitar 35 orang. Kegiatan ini dilaksanakan 1 hari dimulai sekitar pukul 08.00 wib dan berakhir pukul 15.00 wib. Kegiatan pelatihan ini terdiri dari penyampaian materi, diskusi dan latihan menyusun atau membuat anggaran pendapatan dan pengeluaran dengan benar.

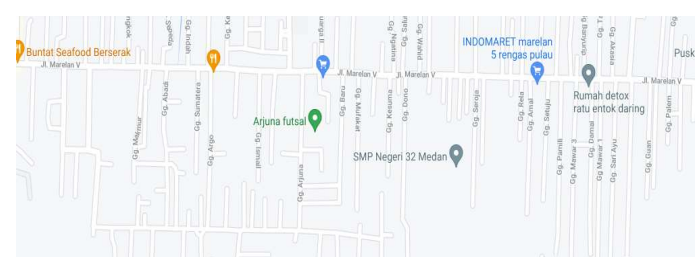

Gambar 1. Peta lokasi Kegiatan Pengabdian Masyarakat di Kelurahan Rengas Pulau, Kecamatan Medan Marelan

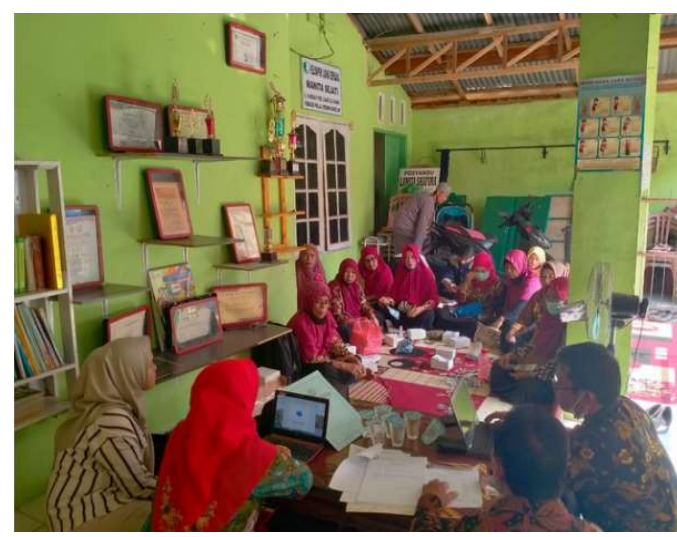

Gambar 2. Penyampaian Materi Pelatihan Perencanaan Keuangan 


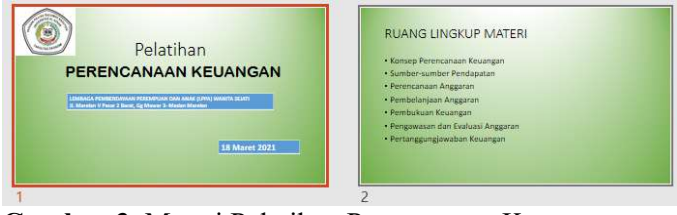

Gambar 3. Materi Pelatihan Perencanaan Keuangan

Berdasarkan hasil observasi awal yang telah dilakukan menunjukkan bahwa peserta belum memahami tentang perencanaan keuangan yang baik. Kesadaran akan pentingnya mengelola keuangan yang rendah mengakibatkan ketidakseimbangan antara pendapatan dan pengeluaran. Para peserta sangat antusias dengan mengikuti jalannya acara sampai selesai. Hal ini terlihat dari kehadiran para peserta yang tepat waktu dan mengikuti acaranya sampai selesai. Para peserta yang hadir sekitar 35 orang peserta yang diundang. Para peserta diberikan materi tentang perencanaan keuangan yang benar, efektif dan efisien sehingga mereka memiliki pengetahuan dan wawasan dalam mengatur keuangan. Para peserta juga diberikan pelatihan menyusun atau membuat anggaran pendapatan dan pengeluaran yang benar. Tujuannya agar para peserta bisa mempraktikkan di Lembaga tersebut maupun dalam kehidupan sehari-hari. Hasil kegiatan pelatihan menunjukkan sekitar $85 \%$ peserta telah memahami anggaran pendapatan dan pengeluaran, mampu menyusun skala prioritas kebutuhan serta mampu menyusun anggaran pendapatan dan pengeluaran dengan benar. Para peserta sangat antusias untuk mengikuti jalannya acara sampai selesai dengan aktif berdiskusi seputar permasalahan pengelolaan keuangan. Para peserta juga menyadari akan pentingnya merubah mindset dan pemahaman seseorang dalam mengelola keuangan. Mereka berharap kegiatan ini bisa dilakukan secara terusmenerus sehingga kemampuan mereka meningkat terutama dalam menyusun anggaran pendapatan dan pengeluaran.

\section{SIMPULAN}

Pelatihan literasi keuangan ini, memberikan dampak positif bagi Ibu-Ibu Lembaga Pemberdayaan Perempuan dan Anak (LPPA) Wanita Sejati, Kelurahan Rengas Pulau Kecamatan Medan Marelan yaitu adanya peningkatan pengetahuan dalam melakukan perencanaan dan pengelolaan keuangan serta peningkatan kemampuan dalam menyusun anggaran pendapatan dan pengeluaran yang benar.

\section{DAFTAR PUSTAKA}

Halim, Yopie Kurnia Erista \& Astuti, Dewi. (2015). IPI Financial Stresor, Financial Behavior, Risk Tolerance, Financial Solvency, Financial Knowledge, dan Kepuasan Finansial: View Article. Jurnal Finesta, 3(1), 19-23.

Ida, I., \& Dwinta, C. Y. (2010). Pengaruh locus of control, financial knowledge, income terhadap financial management behavior. Jurnal Bisnis Dan Akuntansi, 12(3), 131-144. https://doi.org/10.34208/jba.v12i3.202

Mahdzan, Tabiani. (2013). The Impact of Financial Literacy on individual saving an Exploratory Study in the Malaysia Context. 12(1), 41-55.

Siregar, Z. H., Harahap, U. N., \& Masdania Zurairah, S. R. (2020). Perencanan Bahan Baku Menggunakan Metode Min-Max Pada PT. Pacific Palmindo Industri. Talenta Conference Series: Energy and Engineering (EE), 3(2), Article 